\title{
Etnomatematika hasil pembuatan krecek kerupuk rambak kanji dalam penerapan pembelajaran melalui berpikir spasial
}

\author{
Camelia Wahyu Perdani \\ Program Studi Pendidikan Matematika, Universitas Nusantara PGRI Kediri, Kediri, Indonesia \\ E-mail: Cameliaperdani98@gmail.com
}

\begin{abstract}
ABSTRAK
Terdapat aktivitas masyarakat yang erat berhubungan dengan etnomatematika terutama pada pembuatan krecek kerupuk rambak kanji di Kecamatan Pace. Dengan adanya etnomatematika masyarakat dan peserta didik dapat mengetahui keberadaan matematika sebagai ilmu yang tidak hanya berlangsung dikelas semata namun juga ada disekitar kita. Etnomatematika hasil pembuatan krecek kerupuk rambak kanji ini dilibatkan dalam pembelajaran matematika untuk membantu peserta didik dalam meningkatkan dan mengembangkan ilmu matematika dengan menggunakan indikator berpikir spasial. Penelitian ini menggunakan jenis penelitian deskriptif kualitatif. Subjek penelitian ini adalah siswa SD Negeri kelas V dengan hasil yang menunjukkan kemampuan peserta didik kategori tinggi. Pengumpulan data dilakukan oleh peneliti dengan mengerjakan tes soal uraian dan wawancara pada subyek yang terpilih.
\end{abstract}

Keywords: Etnomatematika; Berpikir Spasial; Pembelajaran Matematika;

\section{ABSTRACT}

There are community activities that are closely related to ethno-mathematics, especially in the making of krecek rambak kanji crackers in Pace District. With the existence of ethnomathematics society and students can find out the existence of mathematics as a science that does not only take place in the classroom but also around us. The ethnomatematics resulting from making krecek rambak kanji crackers is involved in learning mathematics to help students improve and develop mathematics by using indicators of spatial thinking. This research uses descriptive qualitative research. The subjects of this study were students of SD Negeri class $V$ with results showing the ability of students in the high category. Data collection was carried out by researchers by taking test questions and descriptions of the selected subjects.

Keywords: Ethnomatematics; Spatial Thinking; Mathematics Learning;

\section{PENDAHULUAN}

Sebagian besar masyarakat banyak yang tidak menyadari telah menerapkan matematika untuk menyelesaikan masalah dalam kehidupan sehari-hari. Utami, Muhtadi, dan Ratnaningsih (2020) mengungkapkan bahwa matematika memiliki sebuah ikatan yang melekat dan tidak terlepas dari kehidupan sehari-hari manusia baik itu di rumah, di lingkungan kerja, di sawah, di kebun, di ladang, di gunung dan di tempat manapun mereka berada. Sedangkan menurut (Rachmawati, 2012) matematika tumbuh dan berkembang karena adanya tantangan hidup yang selalu di hadapi manusia dalam berbagai wilayah yang terdapat keragaman budaya yang berbeda. Dari pendapat diatas dapat disimpulkan bahwa matematika dan budaya memiliki hubungan dan keterkaitan yang sangat erat dan melekat dalam kehidupan manusia, hubungan yang menjembatani antara keduanya disebut etnomatematika.

D’Ambrosio (1985) mengatakan bahwa etnomatematika dapat diartikan sebagai matematika yang dipraktekkan oleh kelompok budaya tertentu seperti masyarakat nasional suku, kelompok buruh, anak- anak dari kelompok usia tertentu dan masih banyak lagi. Sehingga, aktivitas etnomatematika dapat muncul akibat pengaruh budaya yang ada di lingkungan 
sekitar. Salah satu aktivitas tersebut yakni pada industri rumah tangga pembuatan krecek kerupuk rambak kanji yang ada di Kecamatan Pace. Peneliti menggunakan etnomatematika hasil pembuatan krecek kerupuk rambak kanji untuk membantu peserta didik dalam menyelesaikan permasalahan pada pembelajaran matematika di Sekolah Dasar menggunakan indikator berpikir spasial.

Yuda (2011) menyatakan "spatial thinking is a skill fundamental to problem solving in a variety of contexts". Artinya berfikir spasial adalah keterampilan dasar untuk memecahkan suatu masalah dalam berbagai banyak konteks. Dari pernyataan tersebut diharapkan dengan penerapan pembelajaran menggunakan indikator berpikir spasial kita dapat menyelesaian berbagai konteks masalah dalam kehidupan seperti permasalahan pembelajaran matematika. Tujuan penelitian ini untuk mendeskripsikan kemampuan berpikir spasial siswa kategori tinggi melalui etnomatematika industri rumah tangga hasil pembuatan krecek kerupuk rambak kanji.

\section{METODE PENELITIAN}

Metode yang digunakan dalam penelitian ini adalah menggunakan jenis penelitian deskriptif kualitatif dimana data yang dikumpulkan berupa deskripsi kata-kata, gambar dan angka. Data penelitian deskriptif berasal dari naskah wawancara, catatan lapangan, foto, videotape, dokumen pribadi, catatan atau memo, soal tes uraian, dan dokumen resmi lainnya. Pada penulisan laporan, peneliti menganalisis berbagai data tersebut sesuai dengan keadaan aslinya (Moleong, 2017). Sedangkan Sugiyono (2016) berpendapat bahwa metode penelitian kualitatif adalah metode penelitian yang digunakan untuk meneliti objek yang alami, dimana peneliti adalah sebagai instrumen utama, teknik pengumpulan data yang dilakukan dengan triangulasi, analisis data bersifat induktif, dan hasil penelitian dari kualitatif lebih menekankan pada makna dari pada generalisasi.

Dalam penelitian ini, prosedur pengumpulan data yang dilakukan oleh peneliti menggunakan instrumen utama dan instrumen pendukung. Instrumen utama yang dimaksud adalah peneliti dan instrumen pendukungnya adalah RPP, tes soal uraian dan pedoman wawancara. Peneliti menggunakan RPP untuk melakukan pembelajaran kepada siswa kelas V yang selanjutnya peneliti memberikan tes soal uraian untuk mengetahui pemahaman siswa. Peneliti melakukan aktivitas wawancara yang direkam menggunakan audio recorder. Hasil wawancara subyek di transkripkan oleh peneliti yang kemudian dianalisis.

Subjek dalam penelitian ini adalah siswa kelas V SD Negeri 1 Jetis. Teknik analisis data dalam penelitian ini dilakukan dengan mereduksi data, penyajian data, dan verifikasi data. Seperti yang dikemukakan oleh Sugiyono (2016) bahwa aktivitas yang di lakukan oleh peneliti dalam menganalisis data yakni data reduction (reduksi data), data display (penyajian data), dan conclusion draawing/verification (verifikasi data). Keabsahan data yang digunakan dalam penelitian ini menggunakan triangulasi teknik yakni dalam mendapatkan data dari satu sumber yang sama dengan teknik yang berbeda dan apabila data dirasa kurang maa peneliti melakukan member cek. Data yang dihasilkan berupa teks naratif, berdasarkan hasil analisis dan penarikan kesimpulan yang diperoleh.

\section{HASIL DAN PEMBAHASAN}

Tanpa disadari dalam aktivitas masyarakat banyak ditemukan hubungan keterkaitan yang 
erat dengan matematika dalam memecahkan permasalahan di kehidupan sehari-hari. (Perdani, 2019) berpendapat bahwa matematika adalah salah satu cabang ilmu pengetahuan yang penerapan dan penggunaannya berubungan erat dengan aktivitas masyarakat sehingga matematika sering digunakan dalam berbagai aspek kehidupan, seperti dalam mengukur, mengurutkan suatu bilangan dan masih banyak lagi lainnya. Dari pendapat tersebut peneliti menyimpulkan bahwa penerapan dan penggunaan matematika sangat terikat dengan aktivitas masyarakat dalam kehidupan sehari-hari dimanapun mereka berada. (Rachmawati, 2012) menjelaskan bahwa aktivitas matematika merupakan aktivitas yang di dalamnya terjadi proses pengabstraksian dari pengalaman nyata dalam kehidupan seharihari ke dalam matematika atau sebaliknya, seperti aktivitas mengelompokkan, berhitung, mengukur, merancang bangunan atau alat, membuat pola, membilang, menentukan lokasi, bermain, menjelaskan, dan sebagainya. Matematika merupakan ilmu tentang logika, mengenai suatu bentuk, susunan, besaran, dan terdapat konsep-konsep yang saling berhubungan satu dengan yang lainnya. Koentjaraningrat (1986) yang juga mengemukakan bahwa semua aktivitas manusia merupakan budaya karena tindakan manusia dalam kehidupan masyarakat ini tidak memerlukan belajar dalam membiasakannya. Sehingga, dapat disimpulkan bahwa segala hasil dari budaya dan aktivitas yang di kerjakan oleh manusia yang berkaitan dengan aktivitas masyarakat adalah etnomatematika.

Etnomatematika adalah suatu ilmu yang digunakan untuk memahami bagaimana matematika diadaptasi dari sebuah budaya dan berfungsi untuk mengekspresikan hubungan antara budaya dan matematika (Marsigit, Condromukti, Setiana, \& Hardiarti, 2016). Dengan kata lain, etnomatematika dapat didefinisikan sebagai cara-cara khusus yang dipakai oleh suatu kelompok budaya atau masyarakat tertentu dalam aktivitas matematika. Dengan etnomatematika juga dapat mempermudah peserta didik dalam pemahaman matematika melalui budaya sehingga diharapkan dapat memecahkan solusi dari suatu permasalahan pembelajaran matematika (Perdani, 2019).

Dalam proses pembelajaran terdapat beberapa faktor yang berpengaruh terhadap hasil belajar peserta didik. Salah satu faktor tersebut adalah peran seorang guru dalam mengajar, guru dalam proses belajar mengajar harus mengenal peserta didik, yang dimaksud adalah mengenal psikologi peserta didiknya, juga mengenal perkembangan serta kematangan peserta didik. Sehingga, pembelajaran akan berjalan efektif dan efesien. Dengan kata lain peserta didik akan mampu belajar secara aktif dalam merumuskan dan memecahkan masalah yang diberikan. Sebagaimana pendapat Sabri (2007) yang mengemukakan bahwa guru merupakan penentu keberhasilan proses belajar mengajar peserta didik di sekolah, oleh karena itu seorang guru harus memiliki beberapa keterampilan agar tujuan dari proses belajar mengajar dapat tercapai. Melihat gejala tersebut perlu diadakan perbaikan dalam pembelajaran, karena usaha dan strategi yang dilakukan oleh guru selama ini belum berhasil mengaktifkan sebagian besar peserta didik dalam proses pembelajaran tersebut. Dalam pembelajaran tersebut peneliti berperan sebagai guru dengan menggunakan instrumen rencana pelaksanaan pembelajaran (RPP), lembar kerja siswa (LKS), lembar tes soal uraian dan pedoman wawancara hasil etnomatematika pembuatan krecek kerupuk rambak kanji melalui indikator berpikir spasial.

Berpikir spasial adalah salah satu aspek kognisi yang memiliki peranan penting dalam berbagai disiplin ilmu. Dalam mengola suatu objek yang diubah menjadi sebuah informasi atau konsep yang baru diperlukan adanya alat-alat representasi (metode informasi representasi spasial) yakni representasi (Fiantika, Sa'dijah, Qohar, \& Darsono, 2019). Sementara itu, NRC menyatakan "Spatial thinking is a collection of skills. The skills consist of declarative and perceptual forms of knowledge and some cognitive operations that can be used to transform, combine, or othewise operate on this knowledge. The key to spatial thinking 
is a constructive amalgam of three elements of space, tools of representation, and processes of reasoning". Namun, terdapat definisi yang lebih komprehensif mengenai kemampuan berpikir spasial yang dinyatakan oleh Lohman (1996) yakni kemampuan berpikir spasial mungkin dapat didefinisikan sebagai kemampuan untuk menghasilkan, menyimpan, mengambil dan mengubah struktur gambar visual. Dari pendapat diatas bisa ditarik kesimpulan bahwa berpikir spasial memiliki berbagai peran penting dalam disiplin ilmu pengetahuan dari visualisasi sampai penalaran.

Kunci dalam kemampuan berpikir spasial yaitu: Representation. Menurut (Fiantika, et. al., 2019) representasi merupakan proses internal, dimana dalam proses tersebut dibutukan visualisasi untuk membuat ide yang didapat menjadi nyata dan juga dapat dipahami oleh orang lain. Dalam menggali struktur dari kemampuan berpikir spasial, siswa mendiskripsikan bentuk atau pola untuk mengidentifikasi hubungan antar komponenkomponen representasi spasial. Transformation. Menurut (Fiantika, et. al., 2019) terdapat dua jenis transformasi yakni transformasi mental yang merupakan suatu proses perubahan ide yang terjadi pada proses representasi internal dan transformasi aktual yang merupakan suatu proses perubahan bentuk ungkapan yang diberikan baik secara verbal, visual maupun kinestetik. Reasoning (Penalaran). Menurut (Fiantika, et. al., 2019) penalaran merupakan proses berpikir dimana seseorang dapat memvisualisasikan objek yang ada dan juga dapat diterima secara abstrak objek tersebut. Dalam hal ini menarik kesimpulan merupakan pusat dari proses berpikir secara ilmiah (penalaran), memanipulasi, menafsirkan dan menjelaskan informasi secara terstruktur serta dapat menarik kesimpulan.

Peneliti menggunakan instrumen RPP, LKS, lembar tes soal uraian dan pedoman wawancara dalam penelitian. Dalam deskripsi hasil penelitian disajikan yakni bagaimana peneliti menentukan subjek, analisis data dan hasil penelitian mengenai deskripsi hasil belajar siswa kelas $\mathrm{V}$ dalam menyelesaikan tes soal uraian dari etnomatematika hasil obserasi pembuatan krecek kerupuk rambak kanji pada materi statistika sub bab penyajian data melalui berpikir spasial. Peneliti menentukan subyek penelitian kelas V di SD Negeri 1 Jetis yang dipilih berdasarkan pada hasil tes soal uraian secara tertulis yang berkemampuan tinggi. Subyek ditentukan oleh peneliti menggunakan standart deviasi milik Arikunto (2013) yang menghasilkan hasil tes soal uraian siswa berkategori kemampuan tinggi yakni subyek AP. Berikut adalah asil tes soal uraian subyek AP sebagai berikut.

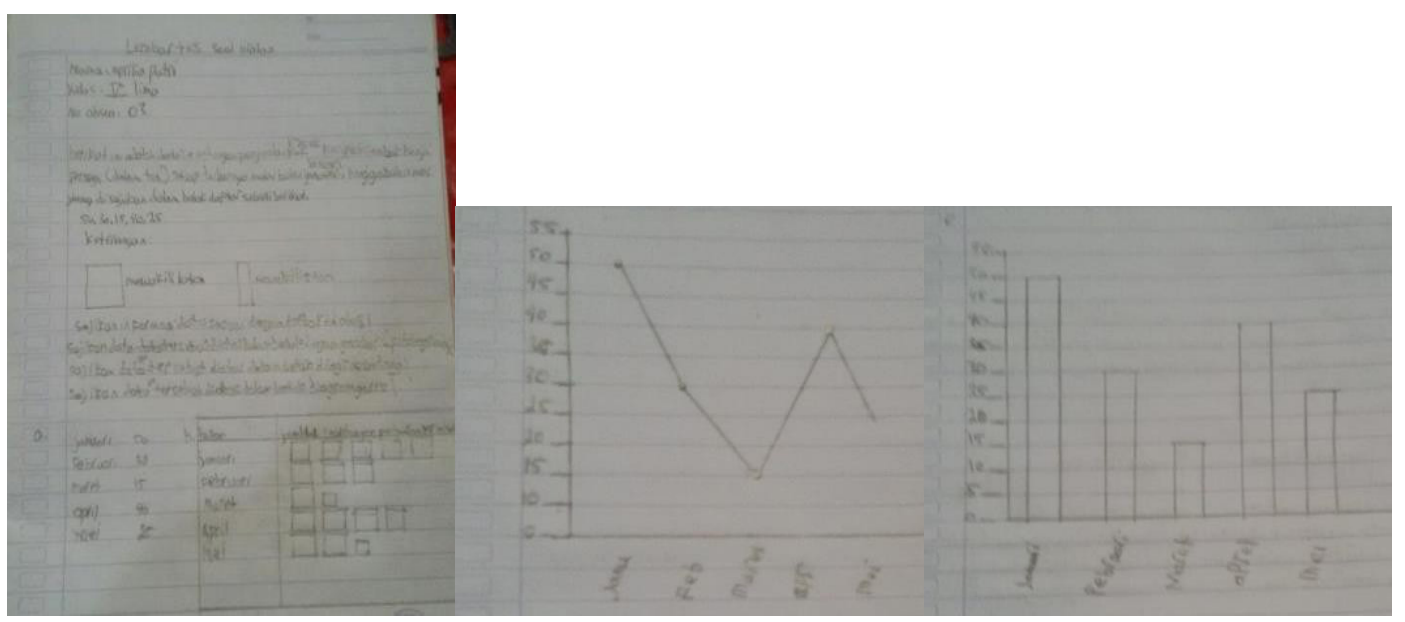

Gambar 1. Lembar Jawaban Subyek AP Secara Tertulis

Berdasarkan jawaban siswa AP diperoleh hasil tes soal uraian kategori berkemampuan tinggi. AP dapat menjelaskan mengenai informasi yang ada dari soal yang diberikan secara urut dan ia juga dapat menggambarkan diagram gambar (piktogram), diagram batang, 
diagram garis dengan benar dan rapi. Selanjutnya peneliti mewawancarai AP, dari hasil wawancara ini digunakan untuk melalukan triangulasi data hasil tes AP.

Peneliti mendeskripsikan berpikir spasial menurut Teori (Fiantika, et. al., 2019) yang mengembangkan indikator berpikir spasial yang terbagi menjadi 3 yakni berpikir spasialvisual yang menghasilkan representasi (BSVR), berpikir spasial-visual yang menghasilkan transformasi (BSVT), dan berpikir spasial-visual yang menjadi penalaran (BSVP).

Tabel 2. Kutipan Wawancara Berpikir Spasial Peneliti dengan Subyek AP

\begin{tabular}{|c|c|c|c|}
\hline No & Komponen Spasial & Deskriptor & Data Hasil Wawancara \\
\hline \multirow[t]{2}{*}{1.} & \multirow[t]{2}{*}{$\begin{array}{l}\text { Berpikir spasial- } \\
\text { visual yang } \\
\text { menghasilkan } \\
\text { representasi (BSVR) }\end{array}$} & $\begin{array}{l}\text { Membuat persepsi } \\
\text { mengenai hasil } \\
\text { observasi krecek } \\
\text { kerupuk rambak kanji } \\
\text { Mengaitkan } \\
\text { pengetahuan dengan } \\
\text { hasil observasi } \\
\text { penyajian data krecek } \\
\text { kerupuk rambak kanji }\end{array}$ & $\begin{array}{l}\text { P : Apa yang kamu ketahui mengenai } \\
\text { hubungan hasil observasi krecek kerupuk } \\
\text { rambak kanji dengan materi penyajian } \\
\text { data? } \\
\text { AP : Dari soal itu mbk saya bisa membuat } \\
\text { diagram gambar, batang dan garis. }\end{array}$ \\
\hline & & $\begin{array}{l}\text { Menghasilkan suatu } \\
\text { informasi dari hasil } \\
\text { observasi krecek } \\
\text { kerupuk rambak kanji } \\
\text { Menyatakan informasi } \\
\text { yang diperoleh } \\
\text { mengenai hasil } \\
\text { observasi krecek } \\
\text { kerupuk rambak kanji }\end{array}$ & $\begin{array}{l}\text { P : Apakah hasil observasi krecek kerupuk } \\
\text { rambak kanji tersebut mempermudah } \\
\text { kamu untuk memahami materi penyajian } \\
\text { data? } \\
\text { AP: Iya. } \\
\text { P : Kenapa? } \\
\text { AP: Karena membuat saya lebih mudah } \\
\text { dalam berfikir, ada gambar juga dan ada } \\
\text { contoh soalnya. }\end{array}$ \\
\hline \multirow[t]{2}{*}{2.} & \multirow[t]{2}{*}{$\begin{array}{l}\text { Berpikir spasial- } \\
\text { visual yang } \\
\text { menghasilkan } \\
\text { transformasi (BSVT) }\end{array}$} & $\begin{array}{l}\text { a. Menyatakan } \\
\text { informasi mengenai } \\
\text { penyajian data dari } \\
\text { hasil observasi krecek } \\
\text { kerupuk rambak kanji } \\
\text { ke dalam berbagai } \\
\text { bentuk diagram }\end{array}$ & $\begin{array}{l}\text { P : Dari data yang diberikan bagaimana } \\
\text { cara kamu menyajikan ke dalam diagram } \\
\text { gambar (piktogram)? } \\
\text { AP : Digambar mbk. } \\
\text { P : Dari data yang diberikan bagaimana } \\
\text { kamu menyajikan data tersebut ke dalam } \\
\text { diagram batang? } \\
\text { AP: (diam berpikir) saya menggaris dan } \\
\text { menggambar diangram batang sesuai } \\
\text { dengan data dari soal. } \\
\text { P : Dari data yang diberikan bagaimana } \\
\text { kamu menyajikan data tersebut ke dalam } \\
\text { diagram garis? } \\
\text { AP: Saya membuat garis sesuai data dari } \\
\text { soal. }\end{array}$ \\
\hline & & $\begin{array}{l}\text { b. Menyatakan ide hasil } \\
\text { observasi penyajian } \\
\text { data krecek kerupuk } \\
\text { rambak kanji berupa } \\
\text { ungkapan }\end{array}$ & $\begin{array}{l}\text { P : Menurut kamu bangun apakah yang } \\
\text { terdapat pada gambar tersebut? } \\
\text { AP: Gambar krecek kerupuk persegi dan } \\
\text { persegi panjang. } \\
\text { P : Kenapa kamu mengategorikan gambar } \\
\text { yang diberikan sebagai bangun tersebut? } \\
\text { AP: Dari gambar mbk itu bentuk persegi } \\
\text { yaitu kotak dan satunya persegi panjang } \\
\text { ada } \\
\text { panjang salah satunya. }\end{array}$ \\
\hline
\end{tabular}




\begin{tabular}{llll}
\hline No & Komponen Spasial & Deskriptor & Data Hasil Wawancara \\
\hline 3. & Berpikir spasial- & a. Menjelaskan proses & P : Bagaimana cara kamu dalam \\
& $\begin{array}{l}\text { visual yang menjadi } \\
\text { penalaran (BSVP) }\end{array}$ & yang dilalui dalam & mengerjakan soal tersebut? \\
& menyelesaikan & MYA : hhmmb dibaca, saya baca dulu lalu \\
& masalah & paham dan saya kerjakan. \\
\cline { 2 - 3 } & b. Menginterpretasi & P : Apa yang kamu ketahui mengenai soal \\
& informasi mengenai & tersebut? \\
& penyajian data dari & AP: Mengenai penjualan krecek kerupuk \\
& hasil observasi krecek & rambak kanji mbk. \\
& kerupuk rambak kanji & P: Dari soal yang diberikan data apa yang \\
& ke dalam tulisan & kamu dapatkan? \\
& (menggunakan bahasa & AP: Krecek kerupuk rambak kanji persegi \\
& sendiri) & dari bulan januari hingga mei.
\end{tabular}

Berdasarkan wawancara, AP dapat mendefinisikan maksud dari soal dan dapat mengetahui apa saja yang ada disoal yang diberikan yakni mengenai daftar penjualan krecek kerupuk rambak kanji persegi dari bulan Januari hingga Mei yang disajikan dalam bentuk daftar pada soal yang selanjutnya dimaksudkan untuk menjelaskan daftar yang ada dan membuat daftar tersebut menjadi diagram gambar (piktogram), diagram batang dan diagram garis. AP juga dapat mengkategorikan bangun datar pada soal tersebut sebagai persegi dan persegi panjang, karena bangun datar tersebut memiliki sisi yang sama, maksudnya adalah bangun datar persegi dan salah satu memiliki sisi yang panjang yakni persegi panjang. Selanjutnya, AP dapat menjelaskan hubungan mengenai soal tersebut dengan materi statistika sub bab penyajian data. AP menyatakan bahwa hasil observasi krecek kerupuk rambak kanji persegi mempermudah dia dalam belajar memahami materi statisika sub bab penyajian data karena disajikan dalam bentuk gambar yang sebenarnya AP sudah tidak asing dengan gambar tersebut, karena gambar hasil pembuaan krecek kerupuk rambak kanji persegi tersebut telah ia kenal dalam kehidupan sehari- hari. Berikut adalah triangulasi teknik dari penelitian yang didapatkan sebagai berikut.

Tabel 3. Triangulasi Teknik Subyek AP berkemampuan tinggi

\begin{tabular}{|c|c|c|c|c|}
\hline No & $\begin{array}{l}\text { Komponen } \\
\text { Spasial }\end{array}$ & $\begin{array}{l}\text { Ketercapaian } \\
\text { Indikator }\end{array}$ & Hasil Tes Soal Uraian & Wawancara \\
\hline \multirow[t]{2}{*}{1.} & \multirow[t]{2}{*}{$\begin{array}{l}\text { Berpikir } \\
\text { spasial- visual } \\
\text { yang menghasil } \\
\text { kan represent } \\
\text { asi (BSVR) }\end{array}$} & $\begin{array}{l}\text { Membuat persepsi } \\
\text { mengenai hasil } \\
\text { observasi krecek } \\
\text { kerupuk rambak kanji } \\
\text { Mengaitkan } \\
\text { pengetahuan dengan } \\
\text { hasil observasi } \\
\text { penyajian data krecek } \\
\text { kerupuk } \\
\text { rambak kanji }\end{array}$ & $\begin{array}{l}\text { AP bisa membuat } \\
\text { diagram gambar, batang } \\
\text { dan garis dari daftar } \\
\text { soal yang diberikan } \\
\text { mengenai hasil } \\
\text { observasi pembuatan } \\
\text { krecek kerupuk rambak } \\
\text { kanji yang memiliki } \\
\text { hubungan dengan } \\
\text { materi statistika sub bab } \\
\text { penyajian data. }\end{array}$ & $\begin{array}{l}\text { AP dapat mengaitkan } \\
\text { diagram gambar, } \\
\text { batang dan garis } \\
\text { dari daftar soal yang } \\
\text { diberikan mengenai } \\
\text { hasil observasi } \\
\text { pembuatan krecek } \\
\text { kerupuk rambak } \\
\text { kanji dengan materi } \\
\text { statistika sub bab } \\
\text { penyajian data. }\end{array}$ \\
\hline & & $\begin{array}{l}\text { Menghasilkan suatu } \\
\text { informasi dari hasil } \\
\text { observasi krecek } \\
\text { kerupuk rambak kanji } \\
\text { Menyatakan informasi } \\
\text { yang diperoleh } \\
\text { mengenai hasil } \\
\text { observasi krecek } \\
\text { kerupuk } \\
\text { rambak kanji }\end{array}$ & $\begin{array}{l}\text { AP mendapatkan } \\
\text { dan menghasilkan } \\
\text { informasi mengenai } \\
\text { materi statistika sub bab } \\
\text { penyajian data dari LKS } \\
\text { yang diberikan sehingga } \\
\text { ia dapat mengerjakan } \\
\text { soal tes uraian tersebut } \\
\text { dengan mudah. }\end{array}$ & $\begin{array}{l}\text { AP merasa terbantu } \\
\text { dalam memahami } \\
\text { materi statistika } \\
\text { sub bab penyajian } \\
\text { data dengan adanya } \\
\text { LKS yang diberikan } \\
\text { sehingga ia dapat } \\
\text { mengerjakan soal } \\
\text { tes uraian tersebut } \\
\text { dengan mudah. }\end{array}$ \\
\hline
\end{tabular}




\begin{tabular}{|c|c|c|c|c|}
\hline No & $\begin{array}{l}\text { Komponen } \\
\text { Spasial }\end{array}$ & $\begin{array}{l}\text { Ketercapaian } \\
\text { Indikator }\end{array}$ & Hasil Tes Soal Uraian & Wawancara \\
\hline \multirow[t]{2}{*}{2.} & \multirow[t]{2}{*}{$\begin{array}{l}\text { Berpikir } \\
\text { spasial- } \\
\text { visual yang } \\
\text { menghasilkan } \\
\text { transformasi } \\
\text { (BSVT) }\end{array}$} & $\begin{array}{l}\text { a. Menyatakan } \\
\text { informasi mengenai } \\
\text { penyajian data dari } \\
\text { hasil observasi krecek } \\
\text { kerupuk rambak kanji } \\
\text { ke dalam berbagai } \\
\text { bentuk diagram }\end{array}$ & $\begin{array}{l}\text { AP dapat menyajikan } \\
\text { diagram gambar } \\
\text { (piktogram), batang dan } \\
\text { garis sesuai dengan soal } \\
\text { yang diberikan dengan } \\
\text { benar. }\end{array}$ & $\begin{array}{l}\text { AP menyajikan } \\
\text { diagram dengan cara } \\
\text { digambar sesuai } \\
\text { bangun datar yang } \\
\text { ada dalam keterangan, } \\
\text { digambar dan digaris } \\
\text { sesuai dengan data } \\
\text { soal yang diberikan. }\end{array}$ \\
\hline & & $\begin{array}{l}\text { b. Menyatakan ide } \\
\text { hasil observasi } \\
\text { penyajian data krecek } \\
\text { kerupuk rambak kanji }\end{array}$ & $\begin{array}{l}\text { AP dapat menyajian } \\
\text { gambar bangun datar } \\
\text { persegi dan persegi } \\
\text { panjang melalui diagram } \\
\text { gambar (piktogram). }\end{array}$ & $\begin{array}{l}\text { AP mengatakan bahwa } \\
\text { bangun datar tersebut } \\
\text { adalah persegi dan } \\
\text { persegi panjang. }\end{array}$ \\
\hline \multirow[t]{2}{*}{3.} & \multirow[t]{2}{*}{$\begin{array}{l}\text { Berpikir } \\
\text { spasial-visual } \\
\text { yang menjadi } \\
\text { penalaran } \\
\text { (BSVP) }\end{array}$} & $\begin{array}{l}\text { a. Menjelaskan proses } \\
\text { yang dilalui dalam } \\
\text { menyelesaikan } \\
\text { masalah }\end{array}$ & $\begin{array}{l}\text { AP mengerjakan soal } \\
\text { yang diberikan. }\end{array}$ & $\begin{array}{l}\text { AP menjelaskan proses } \\
\text { yang dia lalui dalam } \\
\text { mengerjakan soal } \\
\text { yang diberikan secara } \\
\text { singkat. }\end{array}$ \\
\hline & & $\begin{array}{l}\text { b. Menginterpretasi } \\
\text { informasi mengenai } \\
\text { penyajian data dari } \\
\text { hasil observasi krecek } \\
\text { kerupuk rambak } \\
\text { kanji ke dalam tulisan } \\
\text { (menggunakan } \\
\text { bahasa sendiri) }\end{array}$ & $\begin{array}{l}\text { AP dapat menjelasan } \\
\text { secara singkat mengenai } \\
\text { daftar hasil penjualan } \\
\text { krecek kerupuk rambak } \\
\text { kanji yang ada disoal } \\
\text { mulai dari bulan Januari } \\
\text { sampai dengan bulan } \\
\text { Mei. }\end{array}$ & $\begin{array}{l}\text { AP dapat menjelasan } \\
\text { secara singkat } \\
\text { mengenai daftar hasil } \\
\text { penjualan krecek } \\
\text { kerupuk rambak kanji } \\
\text { yang ada disoal mulai } \\
\text { dari bulan Januari } \\
\text { sampai dengan bulan } \\
\text { Mei. }\end{array}$ \\
\hline
\end{tabular}

\section{SIMPULAN DAN SARAN}

Deskripsi hasil penelitian yang dilakukan oleh peneliti menemukan bahwa siswa yang memiliki kemampuan berpikir spasial kategori tinggi dapat melakukan proses berfikir spasial dalam mengerjakan dan menyajikan semua soal menggunakan tes soal uraian hasil etnomatematika pembuatan krecek kerupuk rambak kanji yang diberikan sehingga hasil akhir dari pengerjaan siswa tersebut benar, urut, teratur dan rapi. Siswa tersebut dapat mengaitkan pengetahuannya dalam bentuk informasi ke dalam berbagai jenis diagram dan sangat aktif bertanya apabila mendapatkan kesulitan. Siswa tersebut dapat menemukan hal-hal yang baru dengan menggunakan bahasa mereka sendiri dan dapat mengembangkan hal-hal baru tersebut menjadi sebuah pengetahuan.

Peneliti berharap etnomatematika pada kerajinan pembuatan krecek kerupuk rambak kanji dapat dimanfaatkan sebagai sumber belajar dalam pembelajaran matematika untuk memudahkan siswa dalam belajar, menambah wawasan siswa mengenai keberadaan matematika yang ada pada salah satu unsur budaya yang mereka miliki disekitar tempat tinggal, meningkatkan motivasi dan memfasilitasi siswa dalam mengaitkan konsepkonsep yang dipelajari secara kontekstual. Bagi para pembaca memiliki minat untuk mengeksplorasi lebih lanjut keberadaan etnomatematika yang lainnya terutama yang ada disekitar lingkungan tempat tinggal. 


\section{DAFTAR RUJUKAN}

Arikunto, S. (2013). Dasar-dasar Evaluasi Pendidikan. Jakarta, Indonesia: Bumi Aksara.

D'Ambrosio, U. (1985). Ethnomathematics and Its Place in the History and Pedagogy of Mathematics. For the Learning of Mathematics, 5(1), 44-48. Retrieved from http:// www.jstor.org/stable/40247876

Fiantika, F.R., Sa'dijah, C., Qohar, A., \& Darsono. (2019). Eksistensi Budaya Lokal dalam Konteks Pembelajaran Matematika Masa Kini. Ponorogo, Indonesia: Uwais Inspirasi Indonesia.

Koentjaraningrat. (1986). Pengantar Ilmu Antropologi. Jakarta, Indonesia: Aksara Baru.

Lohman, D. F. (1996). Spatial ability and g. in Dennis, I., \& Tapsfield, P. (Eds) Human abilities: Their nature and measurement (pp. 97-116). Mahwah, New Jersey: Lawrence Erlbaum Associates.

Marsigit, Condromukti, R., Setiana, D.S., \& Hardiarti, S. (2017). Pengembangan Pembelajaran Matematika Berbasis Etnomatematika. in Prosiding Seminar Nasional Etnomatnesia (pp. 20-38). Retrieved from https://jurnal.ustjogja.ac.id/index.php/etnomatnesia/

Moleong, L.J. (2017). Metodologi Penelitian Kualitatif. Bandung, Indonesia: Remaja Rosdakarya.

Perdani, C. W. (2019). Etnomatematika Kajian Pembuatan Krecek Kerupuk Rambak Kanji Pada Home Industri di Kecamatan Pace Dari Sudut Pandang Etnomatematika. Inspiramatika: Jurnal Inovasi Pendidikan dan Pembelajaran Matematika, 5(2). Retrieved from http://e-jurnal.unisda.ac.id/index.php/Inspiramatika/

Rachmawati, I. (2012). Eksplorasi etnomatematika masyarakat sidoarjo. MATHEdunesa, 1(1). Retrieved from https://jurnalmahasiswa.unesa.ac.id/index.php/mathedunesa/

Sabri, A. (2007). Strategi Belajar Mengajar Dan Micro Teaching. Jakarta, Indonesia: Quantum Teaching.

Sugiyono. (2016). Metode Penelitian Kuantitatif, Kualitatif, dan R\&D. Bandung, Indonesia: ALFABETA.

Utami, R., Muhtadi, D., Ratnaningsih, N., Sukirwan, S., \& Hamid, H. (2020). Etnomatematika: Eksplorasi Candi Borobudur. JP3M (Jurnal Penelitian Pendidikan dan Pengajaran Matematika), 6(1), 13-26. DOI 10.37058/jp3m.v6i1.1438

Yuda, M. (2011). Effectiveness of digital educational materials for developing spatial thinking of elementary school students. Procedia-Social and Behavioral Sciences, 21, 116-119. DOI 10.1016/j.sbspro.2011.07.045 